\title{
Measurement of Brand Awareness and Brand Loyalty of Goldstar Shoes
}

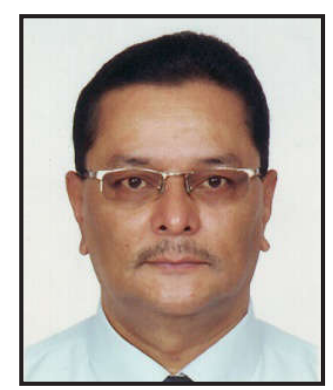

Dr. Kailash Patendra Amatya*

\begin{abstract}
The purpose of this study is to measure the degree of brand awareness and brand loyalty of Goldstar shoes among Nepalese consumers. The study has adopted descriptive research design. Data in the study are collected from primary data. A total of 70 respondents participated in this study. Data were analyzed using various tools such as tables and figures to draw the conclusion. The findings show that majority of consumers are aware about Goldstar shoes and associate them with durability, comfort and price attributes. However, this familiarity is not able to influence the purchase decision of consumers. The manufacturers should manufacturer footwear in various designs and styles using better materials that ensure comfort and durability to consumers along with maintaining reasonable pricing strategy to have a strong customer base loyalty.
\end{abstract}

Key Words: Brand awareness, Brand loyalty, Goldstar shoes.

\section{Introduction}

In recent years, the footwear industry and the business environment have significantly changed and have also become more sophisticated and competitive as a result of globalization. In the past, shoes were used for functional purposes; their purpose in the modern society has changed. The aesthetical style of shoes has taken the equal share of consumer interest as functionality that was a predominant factor for the choice of shoes. Footwear is more likely to be seen as the centerpiece of clothing rather than as accessories (Leathers, 2014). Footwear has become a common and popular category among young people as it has become selfidentification tool that helps individuals to distinguish themselves from the masses with a more relaxed lifestyle, greater versatility and comfort.

According to the report of Packaged Facts (2009), between 2004 to 2008, the global footwear market grew at a compound annual growth rate of six percent. About eighty percent of authentic and athletic footwear as well as active sportswear in the market are branded (Tong \& Hawley, 2009). Newbery (2008) revealed that Nike, Adidas and Reebok are the three global sportswear brands that have thirty-three percent of the global active sportswear and athletic footwear market in 2007. He also argued that the volume of branded footwear is expected to grow and reach approximately 15 billion pairs by 2010 .

* Associate Professor, Shanker Dev Campus, Tribhuvan University, Nepal 
Today, there are plenty of footwear brands available in the market either from the international or local brands to meet the expectation of customers. The footwear market consists of all types of men's, women's and children's shoes (Datamonitor, 2009). The rising of consumer consciousness has made consumers choose to purchase their familiar and favorable brand. Therefore, if businesses want to defeat their competitors; they have to make consumers love to buy their products and brands (Chi, Yeh \&Yang, 2009). Macdonald and Sharp (2000) depicted even though consumers are familiar and willing to buy a product, brand awareness is still an important factor to influence purchase decision. When a consumer is willing to buy a product or service, the first brand name that clicks in his mind shows that this product has higher brand awareness. Dodds, Monroe and Grewal (1991) argued higher level of brand awareness can influence the purchase decision of the consumers. This is one of the reason that why a product having higher level of brand awareness will result in higher share in market and superior evaluations of their quality. On the other hand, businesses must create brand loyalty. Reichheld and Sasser (1990) suggested that it takes 5 times more to cost to attract the new consumers than maintaining the old ones. It means that less cost will be incurred on the product with higher brand loyalty. Assael (1998) defined brand loyalty, "as a favorable attitude of the customer towards a brand which is a result of consistent purchase of the brand over time". In other words, brand loyalty is nothing but a realization by the customer that a particular brand provides him with maximum satisfaction. It is the extent of trust and belief on a particular brand that is represented by the repeat purchases of the brand by the customers despite the knowledge and availability of the other brands existing in the market. Thus, brand loyalty has been proclaimed to be the ultimate goal of marketing.

\section{Objectives}

The specific objectives of the study are listed thoroughly in the statements below:

- To analyze the effect of brand on purchase decision.

- To examine how price is perceived by customers.

- To measure the brand awareness of Goldstar shoes.

- To investigate the degree brand loyalty of Goldstar Shoes.

- To recognize the factors that affect on brand loyalty of Goldstar shoes

\section{Review of Literature}

\section{Brand Awareness}

Brand awareness plays an important factor in any consumer choice decision. Brand awareness means the ability of a consumer can recognize and recall a brand in different situations (Aaker, 1996). Keller (1993) defines brand awareness as a brand recognition and brand recall performance. When a consumer faces a set of different brands, the brand with the highest brand awareness will be preferred, despite the quality and prices of the other brands (MacDonald and Sharp, 2000). 
Brand Loyalty

Brand loyalty is the final destination of brand management, and if a company wants to test the weakness or strength of its customers' loyalty, it can easily check whether consumers still favor its product in contrast to competitors. Brand loyalty is consumer attitudes on a brand preferences from previous use and shopping experience of a product (Aaker, 1991; Deighton, Henderson \& Neslin, 1994), and it can be measured from repurchase rate on a same brand. However, purchase frequency is not equal to loyalty. For instance, consumers to repurchase a product do not mean they like it but due to a convenient factor or a variety seeking behavior to purchase a certain specific product occasionally (Tseng, Liao, and Jan, 2004).

Wong and Yahyah (2008) researched on influence of brand loyalty on consumer sportswear. The research showed that there is positive and significant relationship between factors of brand loyalty (brand name, product quality, price, style, promotion, service quality and store environment) with sportswear brand loyalty.

Allender and Richards (2012) conducted a research on measures of brand loyalty. The findings of the study depicted that in the RTE cereal category the level of brand loyalty was very high. It also highlighted the negative relationship between the strength of the brand and the frequency of price promotions at the retail level.

\section{Research Methods}

\section{Research Design}

The study is descriptive in nature which tries to dig out the hidden reality regarding the understanding of the awareness of Goldstar shoes brand.

\section{Population and Sample}

People who purchased the Goldstar shoes in Kathmandu City is the population of the study of interest. Seventy Nepalese consumers with different lifestyles, age and preference from the few different locations of Kathmandu City are sample of the study.

\section{Nature and Sources of Data}

The study is based on primary data for the fulfillment of the objectives.

\section{Tools Used for Data Analysis}

Various tools such as pie-chart, tables, bar and column diagram are used to analyze the data collected from primary sources in this study.

\section{Data Analysis}

\section{Respondents Profile}

Gender: Majority of the respondents are male i.e. 43 respondents. Similarly, 27 respondents are female in this survey 
Age: 63 respondents are from the age group 15-20 whereas 7 respondents are from the age group 20-30. However, there have not been any respondents from the other age group in this survey.

Occupation: 61 respondents are students whereas 9 respondents are job-holder.

\section{Effect of brand on Consumer Purchase Decision}

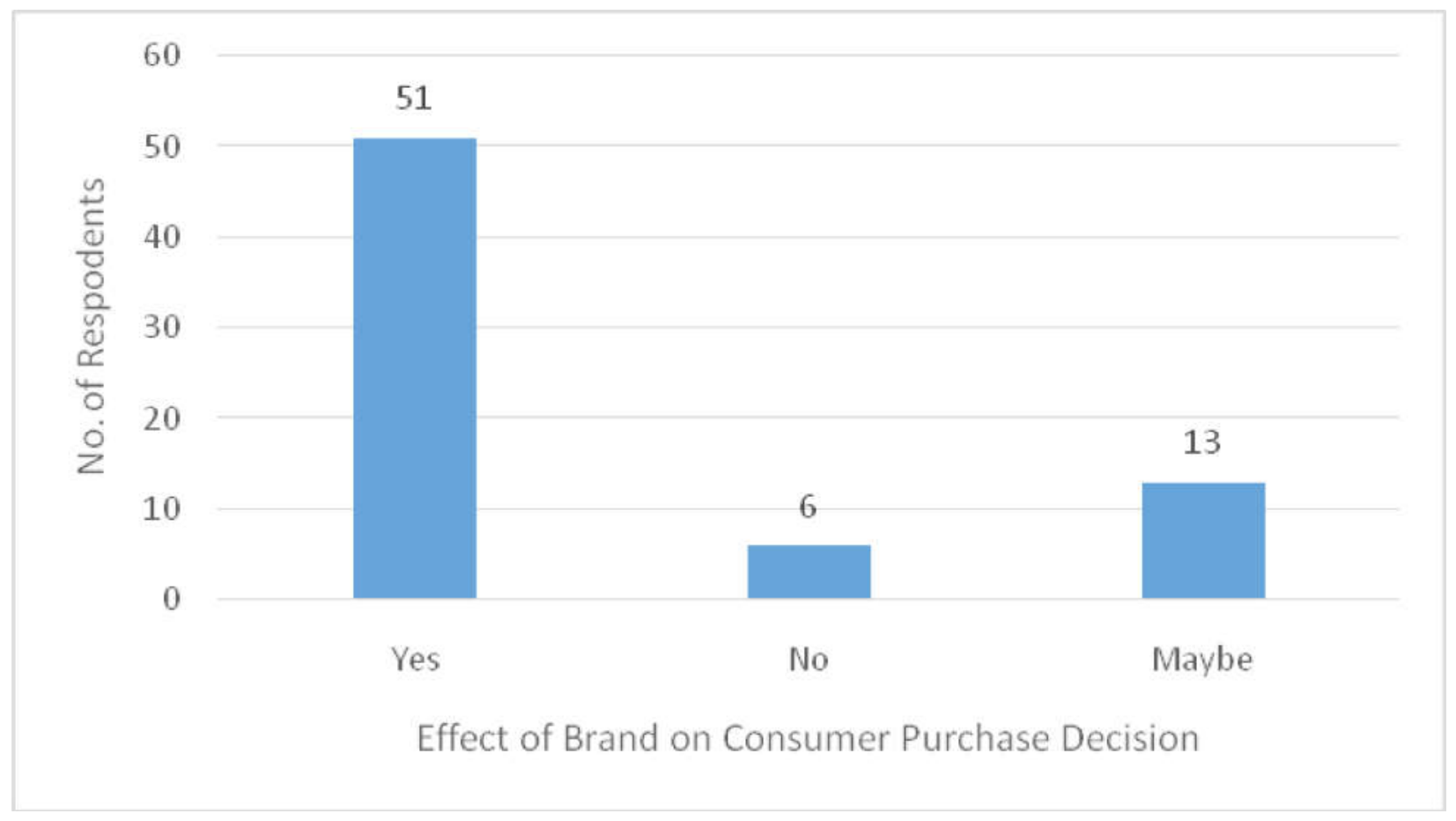

Figure 1: Effect of Brand on Consumer Purchase Decision

Figure 1 shows that 51 respondents consider the brand while purchasing a pair of shoes whereas 6 respondents do not consider the brand of shoes. Similarly, 13 respondents have said that they may or may not consider the brand of shoes depending on the situational and economic factors. 
Price of Goldstar shoes

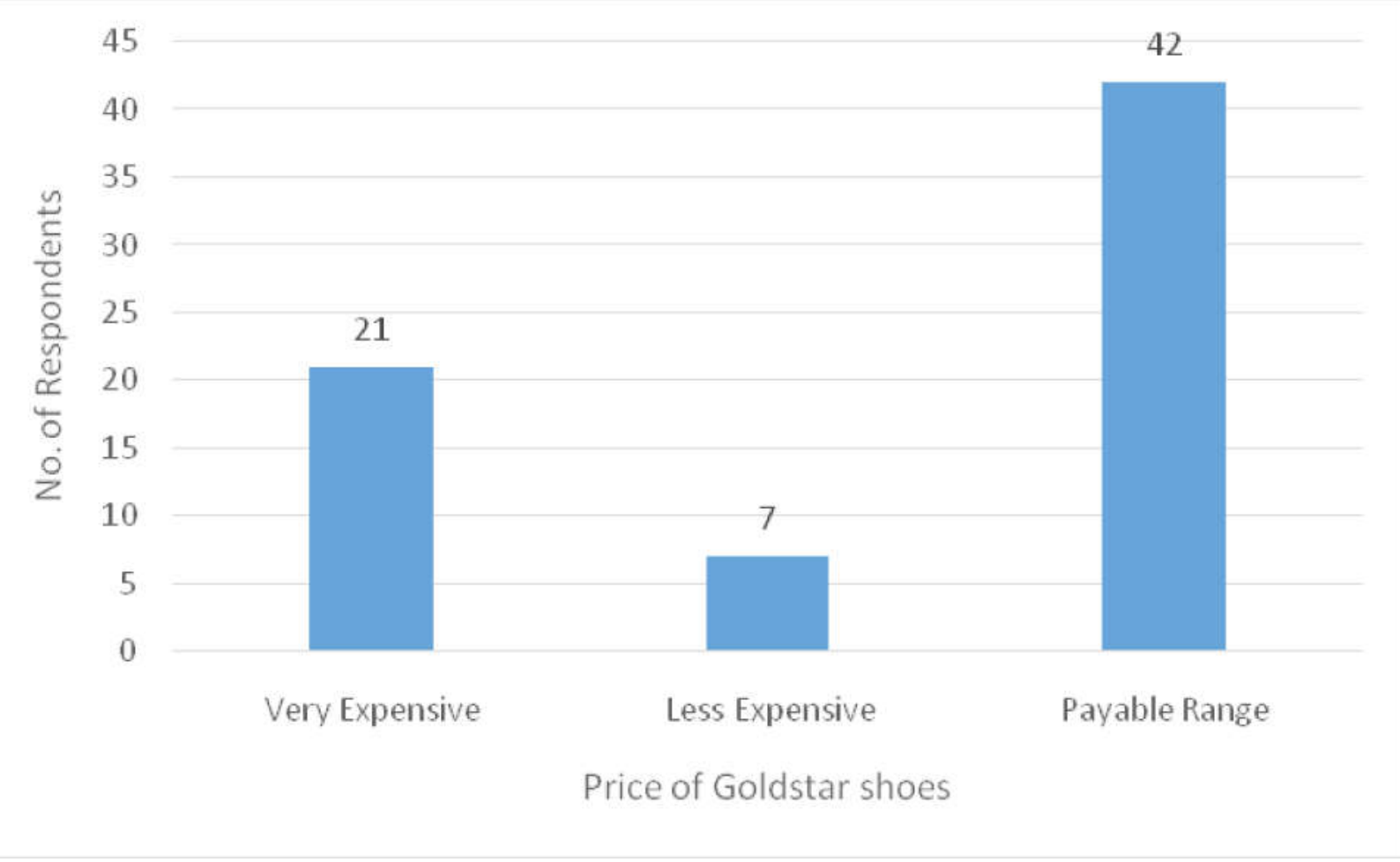

Figure 2: Price of Goldstar shoes

Figure highlights 42 respondents' feels that Goldstar shoes are at their price range. 21 respondents consider the price of Goldstar shoes as very expensive, 7 respondents consider the price as less expensive.

\section{Measuring the brand Awareness of Goldstar Shoes}

Top-of-Mind of consumers. Out of 70 respondents, 26 respondents reveal that Adidas come to their mind when they think of a shoe brand. Similarly, Nike and Goldstar stand in second and third range with respondents of 21 and 9 accordingly. Reebok and other shoe brand (not mentioned in the questionnaire) have equal respondents (i.e. 5 respondents of each shoe brand). However, from above bar-diagram, respondents seem to be less aware about Sikhar Shoes.

Familiarity with GOLDSTAR Shoes. 99 percent of the total respondents are familiar with Goldstar shoes whereas $1 \%$ of the total respondents have never heard about them.

Attributes associated with GOLDSTAR Shoes. 26 respondents associate Goldstar shoes with comfort. Similarly, durability and price has been considered as primary attribute associated with the Goldstar shoes by equal number of respondents i.e. 20 respondents of each attribute. 3 respondents associate other attributes (which has not been mentioned in the questionnaire) 
with Goldstar shoes. Style of the product is considered by only one respondent as an attribute associated with the brand.

\section{Understanding the Degree of Brand Loyalty of Goldstar Shoes}

Chances of Recommendations. 9\% respondents will recommend Goldstar Shoes as excellent, $30 \%$ respondents will recommend as very good and $44 \%$ will recommend as good to friends and relatives. Similarly, $13 \%$ and $4 \%$ respondents have recommended Goldstar Shoes as fair and poor brand accordingly to friends and relatives.

Usage/Purchase duration of Goldstar Shoes. 27 respondents said that they have been using GOLDSTAR Shoes recently. 13 and 3 respondents claimed of using GOLDSTAR Shoes from last 5 and 10 years respectively.

Repurchase frequency of Goldstar Shoes. 11 respondents regularly repurchase GOLDSTAR Shoes. Similarly, 44 and 9 respondents repurchase sometimes and rarely respectively. However, 6 respondents say that they will never repurchase GOLDSTAR Shoes.

Chance of switching to other brands. $54 \%$ of the total respondents said they may or may not switch to other shoe brands depending on other situational and moderating factors whereas $26 \%$ of total respondents said they would switch to other brands given the choice of other shoe brands for purchase. Only 20\% respondents said they would not switch to other shoe brands even if there preferred brands are not available in the market and are given the choice of other shoe brands for purchase.

\section{Conclusion}

In today's competitive world where most of the organizations are involved in innovating new product and services to attain a wide market coverage and earn more profit, building Brand Awareness and Brand Loyalty is one of the basic objective of every organization to be successful leader in the market. The awareness of the brand plays a significant role while purchasing a product or service and may have control on perceived risk evaluation of consumers and their level of assurance about the buying decision due to awareness with the brand and its uniqueness. Brand awareness is very important because if there will be no brand awareness no communication and no transaction will be occur (Percy, 1987). Similarly, brand loyalty is very important for the organization to meet its objective so the organization tries to make its customers happy and also resolve the problems if they feel related to their particular product and service.

The study also reveals that comfort, durability and price attribute of the GOLDSTAR Shoes affect the brand loyalty of consumers. As Nepalese consumers tend to be more price and quality sensitive, they are more likely to switch to other brands if the product fails to meet the performance expectation of the consumers in relation to price paid for obtaining the product. 
Similarly, the study shows that majority of consumers are aware about the GOLDSTAR Shoes. However, this familiarity is no able to influence the purchase decision of mass consumers.

Consumers, especially youths, are looking for wide varieties of style. Therefore, the manufacturers should concentrate more on introducing different kinds of varieties footwear with stylish designs according to expectation of youth consumers.

The materials and colors of footwear are also important factors among the consumers for selecting their footwear. Therefore, it is suggested that the manufacturer should concentrate more on manufacturing foot wears with better materials and different colors. Size of the footwear is most important aspects for users to select their brand. Thus, the manufacturer should be very conscious in manufacturing footwear in proper size.

\section{References}

Aaker, D. A. (1996). Measuring brand equity across products and markets. California Management Review, 38(3), 102-121.

Allender, W. J., \& Richards, T.J. (2012). Brand loyalty and price promotion strategies: An empirical analysis. Journal of Retailing, 88(3), 323-342. doi: http:/ / dx.doi.org/10.1016/j. jretai.2012.01.001

Assael, H. (1998). Consumer behavior and marketing Action (6th ed.). Cincinnati, Ohio: SouthWestern.

Chi, H. K., Yeh, H. R., \& Yang, Y. T. (2009). The impact of brand awareness on consumer purchase intention: The mediating effect of perceived quality and brand loyalty. The Journal of International Management Studies, 4(1), 135-144.

Datamonitor. (2009). Global Footwear. Retrieved from https:/ /www.datamonitor.com/

Deighton, J., Henderson, C.M., \& Neslin, S.A. (1994). The effect of advertising on brand switching and repeat purchasing. Journal of Marketing Research, 31, 28-43.

Dodds, W.B., Monroe, K.B., \& Grewal, D. (1991). Effects of price, brand, and store information on buyers' product evaluation. Journal of Marketing Research, 28(3), 307-319.

Keller, K. L. (1993). Conceptualizing, measuring, and managing customer-based brand equity. Journal of Marketing, 57(1), 1-22.

Leathers, W. (2014). Attitude, color and trend forecast. Retrieved from http:/ / wolverineleathers. com/wp-content/uploads/ A14W15-TrendReport-rl.pdf.

Macdonald, E. K., \& Sharp, B. M. (2000). Brand awareness effects on consumer decision making for a common, repeat purchase product: A replication. Journal of Business Research, 48, 5-15. 
Newbery, M. (2008). Global market review of active sportswear and athletic footwear - forecasts to 2014: 2008 Edition. Just-style. Retrieved from http://www.juststyle.com/store/ samples/2009_aroq_sportswear_sample.pdf.

Packaged Facts. (August 2009). The global footwear market: Athletic and non-athletic shoes. Rockville, Maryland.

Reichheld, F., \& Sasser, W. E., Jr. (1990). Zero defections: quality comes to services. Harvard Business Review, 68, 105111.

Tong, X., \& Hawley, J. M. (2009). Measuring customer based brand equity: Empirical evidence from the sportswear market in China. Journal of Product and Brand Management, 18(4), 262271.

Tseng, Y. M., Liao, B. C., \& Jan, Y. S. (2004). The study of relation between product value, brand trust, brand affect and brand loyalty. Journal of Business Administration, 6(1), 29-50.

Wong, F. Y., \& Yahyah, S. (2008). Influence of brand loyalty on consumer sportswear. International Journal of Economics and Management, 2, 221-236. 